\title{
IAMJ
}

INTERNATIONAL

AYURVEDIC

MEDICAL JOURNAL

Review Article

ISSN: 2320-5091

Impact Factor: 6.719

\section{AAMVISHA JANYA AMLAPITTA AND ITS AYURVEDIC MANAGEMENT}

\author{
Abhijeet Sawant ${ }^{1}$, Ajay Kumar ${ }^{2}$, Santosh Kumar Vishwakarma ${ }^{3}$ \\ ${ }^{1,2}$ Post Graduate Scholar, Dept. of Agada Tantra Evam Vidhi Vaidyaka \\ ${ }^{3}$ Asst. Professor, Dept. of Agada Tantra Evam Vidhi Vaidyaka \\ Government Ayurvedic College \& Hospital, Patna, Bihar, India
}

Corresponding Author: dr.abhijeet.patna@gmail.com

https://doi.org/10.46607/iamj3309102021

(Published Online: October 2021)

Open Access

(C) International Ayurvedic Medical Journal, India 2021

Article Received: 27/09//2021 - Peer Reviewed: 07/10/2021 - Accepted for Publication: 08/10/2021

\section{Check for updates}

\begin{abstract}
Agni is one of the important aspects of Ayurveda, which affects the health status of human being up to great extent. As per modern science, Agni can be correlated with digestive fire mainly performs functioning of digestion $\&$ metabolism. In Ayurveda Jatharagni, Dhatwagni and Bhutagni are three types of Agni among which Jatharagni is most important, which generates metabolic transformations (Ahara paka), and this metabolic transformation of ingested foods provides nutrition to the body. If the formation of Ahara paka does not take place properly due to any causative factors then production of Aam/Aamvisha occur and abnormal physiological functioning may be observed which leads to disease like Ajirna, Amlapitta etc.

Acharya Kashyap is the first person who mentioned Amlapitta as a separate disease. He has not given an only vivid description of Amlapitta, but also its treatment too mentioned in Kashyap Samhita. Considering this aspect present article summarized some clinical manifestations of Aam/Aamvish janya Amlapitt and its management by Ayurveda.
\end{abstract}

Keywords: Agnidusti, Aam, Aamvisha, Amlapitta. 


\section{INTRODUCTION}

The digestive \& metabolic activities of the body govern through the Agni which not only perform digestion and assimilation of food but also contributes greatly towards the growth and development of the body. The transformation of food into nutritional energy takes place through Agni which further governs the normal physiological functioning of the body. The disturbance in Agni leads to Agni Dushti which further accumulates many pathological ailments such as Ajirna, aamdosa, aamvisha etc. The normal functioning of Agni provides Bala, Ayu, Swasthyam, Ojha, Utsaha, Teja and Prabha thus helping to maintain good physical and mental status. On the other hand, improper functioning of Agni leads to Agni Dusthi resulting in the production of Aam \& Aamvish, which is the major causative factor for many digestive and metabolic diseases. The Aamvish and diseases associated with disturbed functioning of Agni increasing day by day due to the unwholesome consumption of dietary materials. Ajirna is associated with irregular digestion of ingested food and the prolog situation of Ajirna can lead production of Ama which circulates through the Srotas and affect the normal physiological functioning of the body.

\section{Etiological Factors of Aamvisha}

\section{Aharaja Hetu (Dietary Factors)}

The first and the foremost group of etiological factors of Aamvisha may be considered as the dietary factors. Under this group the intake of food against the Ahara Vidhi Vidhana (dietetic rules) and Ashta Ahara $V_{\text {Viseshayatana }}{ }^{1}$ (Causative factors responsible for the wholesome and unwholesome effect of the methods for diet intake).

(a) According to the type of Ahara- Kulattha, Pruthuka, Pulaka (Husky food). (b) According to the quality of food- Abhisyandi, Atisnigdha (Unctuous), Atiruksha (Very coarse and dry), Gurubhojana (heavy diet) and Vidahi AnnaPana.

(c) According to the Samskara of the Ahara-. Apakwanna (uncooked food) Bhristadhanya (Roasted paddy), Ikshuvikara (Sugarcane products), Pishtanna (flour).

(d)Faulty dietary habit

Ajirnashana (intake of food in indigestion condition), AtiPana (Over drinking), Virruddhasana (Incompatible diet), Intake of kosthavirrudha Ahara, Akalabhojana (untimely eating). Vishamashana (Consumption of food in unhygienic conditions which can lead infections)

Viharaja Hetu (Lifestyle Related Causative Factor) Atisnana (Taking excessive bath), Bhuktwadiwasvapna (Sleeping immediately after meals in the daytime), Vega Vidharana (Suppression of natural urges), Shayya Prajagarana (Improper sleeping schedule).

\section{Manasika Hetu (Psychological Factors)}

Abnormal psychology, in terms of anger, anxiety, greediness etc. would affect the physiology of digestion. Either there would be a lesser secretion of the digestive juice or secreted at an improper time and sometimes it may be secreted in excessive quantity. All these conditions lead to indigestion which ultimately gives rise to Aam visha.

\section{Agantuja Hetu (Miscellaneous Factors)}

Allied factors can be taken under this factor. Under this group constant and excessive consumption of alcohol, tobacco, beverages, smoking may induce the formation of Aamvisha. 


\section{SAMPRAPTI (PATHOGENESIS) OF AAMVISH}

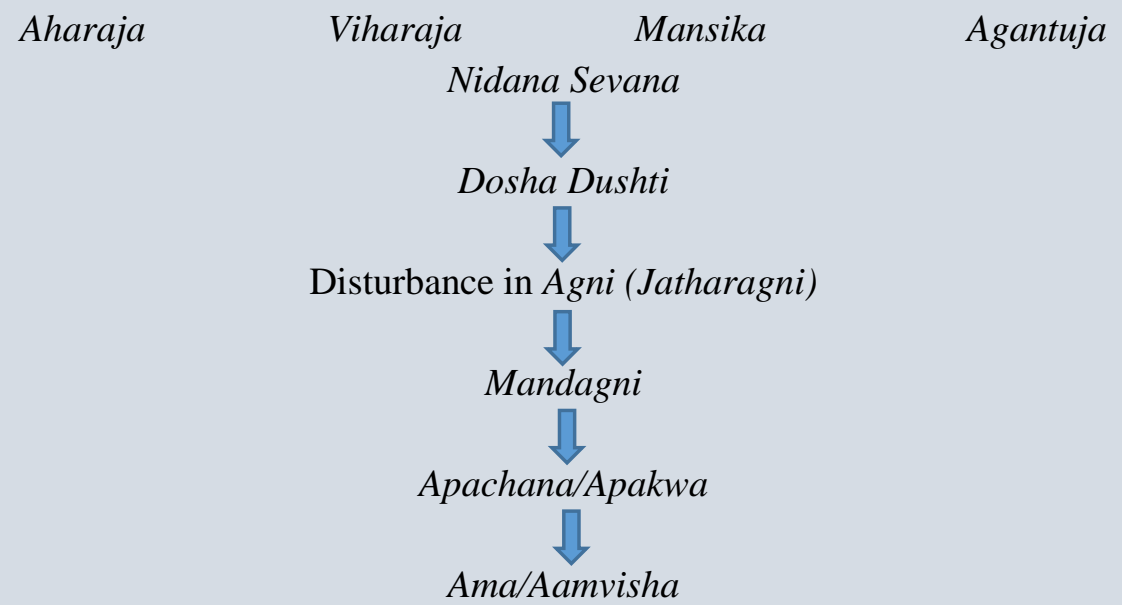

\section{Amlapitta Samhita Review}

Acharya Charaka has not mentioned Amlapitta as a separate disease, but he has given many scattered references regarding Amlapitta, For ex-

While explaining the indications of Ashtavidha Ksheera \& Kansa Haritaki, Amlapitta has also been listed. ${ }^{2}$ and Kulattha (Dolichos biflorus Linn.) has been considered as the chief etiological factor of Amlapitta in Agrya Prakarana. ${ }^{3}$
In Susrutha Samhita while describing the diseases caused by excessive use of Lavana, mentioned $a$ disease called "Amlika" which is like Amlapitta. ${ }^{4}$

Acharya Kashyapa is the first person who mentioned Amlapitta as a separate disease entity. Not only vivid description of Amlapitta but also its treatment too mentioned in Kashyapa Samhita. ${ }^{5}$

Acharya Madhavakar has given a detailed description about Amlapitta including classification of the same according to Gati i.e., Urdhavaga Amlapitta and Adhoga Amlapitta. ${ }^{6}$

\section{Etiology Of Amlapitta According To Kashyapa Samhita}

\begin{tabular}{|l|l|}
\hline Nidana & Effects On Body \\
\hline Viruddha (Incompatible foods) & Tridosha Prakopa \\
\hline Adhyashana (Eating too soon after a meal) & Agnimandhya, Kapha Prakopa \\
\hline Ajeerana (Indigestion) & Agnimandya \\
\hline Ama (Undigested food) & Agnimandhya \\
\hline Pishtaanna (Food prepared from flour) & Kapha Pitta Prakopa \\
\hline Apakva Madhya (Unformed alcohol) & Pitta Kapha Prakopa \\
\hline Apakva Ksheera (Unformed milk) & Kapha Prakopa \\
\hline Guru Bhojana (Heavy food) & Kapha Prakopa \\
\hline Abhishyandi Bhojana (food that causes hypersecretion) & Kapha Prakopa, Eshat Pitta Prakopa \\
\hline Vega Dharana (Withholding urges) & Vata Prakopa \\
\hline Atyushna Atisevanaat (Over intake of hot things) & Pitta Prakopa \\
\hline Snigdha Atisevanaat (Over intake of oily things) & Kapha Prakopa \\
\hline Ruksha Atisevanaat (Over intake of dry things) & Vata Prakopa \\
\hline Amla Atisevanaat (Over intake of sour things) & Pitta Kapha Prakopa \\
\hline Drava atisevanaat (Over intake of liquid things) & Pitta Prakopa \\
\hline
\end{tabular}




\begin{tabular}{|l|l|}
\hline Phaanita (Inspissated juice of sugar cane) & Pitta Prakopa \\
\hline Kullatha (Dolichos biflorus) & Pitta Prakopa \\
\hline Brishtadhanya (Fried grain) & Vata Prakopa \\
\hline Repeated day sleeping after eating & Kapha Prakopa, Agnimandhya \\
\hline Taking bath after intake of food & Kapha Pitta Prakopa \\
\hline Ati Svedana (Excessive sweating) & Pitta Prakopa \\
\hline Taking water in between food & Agnimandhya \\
\hline Paryushita Ahara Sevana (Stale food) & Tridosha Prokop \\
\hline
\end{tabular}

\section{Causes Of Amlapitta As Per Modern Medical Sci- ence}

The most important causative factors of Amlapitta are the excessive use of oily and spicy foods. Irregular eating habits, Excess use of leafy vegetables, Consumption of maida products in large quantity, sleeping after meals, Carbonated drink, Excessive intake of the caffeine and nicotine products, Excessive intake of alcohol, smoking, keeping stomach empty for a long time, skipping breakfast, Constipation, Anxiety, depression and anger, Excessive use of Analgesics esp. NSAIDs.

\section{Samprapti (Pathogenesis) Of Amlapitta}

Due to all these Nidanas (Etiological factors), Vatadi Doshas gets aggravated and causes Mandaagni thereby causing mildness of the Agni (Gastric fire) and the food remains in the Amashaya (abdomen) and turns to Shukta Avastha due to improper burning results in the formation of Aamvisha Due to excessive intake of food due to his greed the Pitta gets vitiated in Drava Roopa and this disease is called as Amlapitta. $^{7}$

\section{Clinical Symptoms Of Amlapitta}

Avipaka (Indigestion), Tikta-Amla Udgara (Bittersour eructations), Aruchi (Loss of appetite), Gaurava (Heaviness in the body), Klama (Mental fatigue), Utklesha (Nausea), Hrita-Kantha daha (Retrosternal burning), Udara- Adhamana (Flatulence), Chhardi (Vomiting), Shiro-ruja (Headache), Antrakujana (Gurgling of the intestine), Vidbheda (Diarrhoea), Romharsha (Horripilation), Hrita Shula (Pain in heart region). ${ }^{8}$

\section{Sadhyasadhyata (Prognosis) ${ }^{9}$}

1. Amlapitta of recent origin (Naveen Amlapitta) is Sadhya.

2. Chronic Amlapitta is Yapya (maintainable).
3. If proper dietic care is taken, an even Kasta-Sadhya type of Amlapitta is treatable.

\section{Management Of Amlapitta}

According to Acharya Charak, Chikitsa (management) of all diseases can be divided in 3 parts-

\section{Nidan parivarjan \\ 2. Sanshodhana \\ 3. Shamana \\ Nidan Parivarjan}

Nidan parivarjan means Withdrawal of the etiological factors of the disease is called nidan parivarjana. Acharya Sushruta mentioned nidana parivarjana as the first line of treatment of all diseases. ${ }^{10}$ In amlapitta excessive nidana sevana leads to Mandagni and Pitta vriddhi. So nidan of amlapitta should be removed in its first treatment. Meals should be of small volume. Alcohol, fatty food and caffeine should be avoided. The drawback of caffeine in coffee and tea is that it increases acid production in the stomach if consumed excessively. Avoid artificial stimulants, all of which raise Aam \& pitta. Alcohol, in any form, is like throwing fuel on the pitta fire.

\section{Sanshodhana Chikitsa}

Samshoshana karma eliminates the vitiated doshas from their root cause and thus cures the disease entirely so that there is the least probability of recurrence of the disease. Acharya Kashyap has mentioned Amlapitta is developed from Amashaya (stomach) and kapha and pitta dosha are having ashrayas. Vamana and virechana karma as the best treatment for Amlapitta. $^{11}$

\section{Drugs used for Vamana and Virecahan}

When the Doshas are in exciting form and moving upwards no other Drava Aushadi except emetics should be given because it will not undergo digestion due to Agnimandhya. ${ }^{12}$ Emesis should be induced with salt 
lukewarm water or with sugar cane juice or with honey water or with bitter drugs. ${ }^{13}$ A combination of Triphala (Terminalia chebula Retz, Terminalia bellirica. Gaertn, Emblica Officinalis Gaertn) or Trivrit (Operculina turpethum $(L$.$) should be taken for attaining$ Virechana.

\section{Sanshamana Chikitsa}

After the Shodhan Karma, the residual Doshas should be pacified by Langhana and Laghu Bhojana and by using the Shamana and Pachana Aushadis. Sanshamana Chikitsa means Prakruti Vighata. Milk is excellent in this condition. The milk diet should adhere to several weeks if possible. Along with this, drink warm water. For a time, it is better to use foods requiring only moderate mastication, since mastication naturally increases the flow of gastric juice with its acid. Yet insufficient mastication of the food chosen will aggravate by causing gastric irritation. So, mastication should always be moderate in this condition. It is important not to overeat, but to take small meals, three times a day.

Acharya Kashyap has used the Guna Siddantha (ie Tikta Rasa contains Ruksha + Sheeta guna which is against the Ushna and Drava Guna of Pitta. ${ }^{14}$ The peculiarity of Kashyap Samhita is that Acharya says to shift the place where all the above-told treatment modalities fail because a person living in Anupa desha is prone for Amlapitta and Anupa Desha is an Ahita Desha according to Acharya Charaka So this is one of the unique method adopted by Acharya Kashypa in the preventive aspect of the disease. ${ }^{15}$

\section{Oral Medication}

1. Avipattikara churna

2. Sutsekhar ras

3. Kamadugha ras

4. Prawal panchamrit

6. Churnas like Shatavari, Yastimadhu, Sariva, Vasa, Bhringa, Dhamasa, Amla, Chandan, Guduchi satwa to be considered.

7. Asav \& Arista like Chandanasav, Ushirasav, kumariashav, Abhayarishta.

\section{DISCUSSION}

Amlapitta is a dominant disease in the present scenario of unhealthy food habits and regimens. Amlapitta is mainly due to aggravation of Aam \& Pitta Dosha. Aggravation of these Dosha is due to excessive intake of spicy and sour food items, alcoholic preparations etc. Anger, fear, excessive exposure to sun and fire, intake of dry vegetables and alkalis, irregularity in taking food etc also cause Dosh dusti results in $\mathrm{Ag}$ nimandhata \& production of Aamvisha janya Amlapitta. The Brahtrayi Granthas has a scattered reference about the Amlapitta but doesn't give a detailed explanation or protocol of treatment for Amlapitta. Acharya Kashypa was the first person to give a detailed protocol of treatment for Amlapitta. Acharya instructs to do Vamana where the Dushita Drava (Aam) yukta Pitta goes out and Agni gains its normalcy. After this, Aushadi is given to do the Pachana of Dosha and further is eliminated from the body through purgation. Advice for change of place in Amlapitta treatment is also considered as the peculiarity of Kashyapa Samhita where the Acharya says to change the habitat where all the above treatment modality fails.

\section{CONCLUSION}

The first and the foremost group of etiological factors of Aamvisha may be considered as the dietary factors. A review has been taken through classical Ayurvedic Text. Charak Samhitas, Vagbhat as well as modern aspects, reveals that as we know the prevention is better than cure, so everybody should obey the rules of intake of food and behaviour to avoid Aamvisha \& Aamvisha janya Amlapitta (Hyperacidity)

Kashypa Samhita even though deals with mainly Kaumarbrithya. Due to the incidence and importance of Amlapitta, Acharya may have given a detailed explanation of Amlapitta and its way of approach in management. Acharya has followed the line of Ama Pachana, and in the Samana aspect. 


\section{REFERENCES}

1. Agnivesha. Charaka Samhita. YadavjiTrikamji Acharya, editor. 1st ed. Varanasi: Chaukhambha Surbharati Prakashan; 2008

2. Vaidya Jadavaji Trikamji Acarya, Caraka Samhita Ayurveda Dipika Commentary of Cakrapanidatta. Edited Chaukhamba Sanskrit Sansthana Varanasi; Fifth Edition, 2001. p22, p487

3. Vaidya Jadavaji Trikamji Acarya, Caraka Samhita Ayurveda Dipika Commentary of Cakrapanidatta. Edited; Chaukhamba Sanskrit Sansthana Varanasi; Fifth Edition, 2001.p131

4. Jadavaji Trikamji Acarya Susruta Samhita- Nibandhasangraha Commentary of Shri Dalhanacarya, Edited; Chaukhamba Orientalia Varanasi, Seventh Edition 2002.p175

5. Pandit Hemraja Sharma, editor. Kashyapa Samhita with Vidhyotini Hindi commentary. Khil Sthana Chapter 16. Verse 3-6. 3rd ed. Varanasi: Chaukhamba Sanskrit Series Office; 2008. p.335

6. Madavkara, Madhava Nidana Madhudukosa Commentary 2nd part Shriyadunandanopadhyay Chaukhambha Sanskrit Sansthan Varanasi chapter 51/3; 204.

7. Pandit Hemraja Sharma, editor. Kashyapa Samhita with Vidhyotini Hindi commentary Khil Sthana Chapter 16. Verse 7-13. 3rd ed. Varanasi: Chaukhamba Sanskrit Series Office; 2008. p.335

8. Pandit Hemraja Sharma, editor. Kashyapa Samhita with Vidhyotini Hindi commentary Khil Sthana Chapter 16. Verse 7-13. 3rd ed. Varanasi: Chaukhamba Sanskrit Series Office; 2008. p.335

9. Pandit Hemraja Sharma, editor. Kashyapa Samhita with Vidhyotini Hindi commentary Khil Sthana Chapter 16. Verse 7-13. 3rd ed. Varanasi: Chaukhamba Sanskrit Series Office; 2008. p.335

10. Susruta, Susruta Samhita Edited with Ayurved tatva sandipika By Kaviraja Ambikadutta Shastri Chaukhambha Sanskrit Sansthan Varanasi uttar tantra 1/25.

11. Pandit Hemraja Sharma Editor Kashyap Samhita with the Vidyotini Hindi commentary Chaukhambha Sanskrit Sansthan Varanasi khil sthan 16/18-19; 336.

12. Pandit Hemraja Sharma, editor. Kashyapa Samhita with Vidhyotini Hindi commentary Khil Sthana Chapter 16. Verse 7-13. 3rd ed. Varanasi: Chaukhamba Sanskrit Series Office; 2008. p.335
13. Pandit Hemraja Sharma, editor. Kashyapa Samhita with Vidhyotini Hindi commentary Khil Sthana Chapter 16. Verse 7-13. 3rd ed. Varanasi: Chaukhamba Sanskrit Series Office; 2008. p.335

14. Vagbhatta, Ashtangahridaya, Kaiviraj Atridev Gupta edited by Yadunandan Upadhyaya 13th edition, Chaukhamba Sanskrit samsthana, Varanasi, 2000 p 174

15. Agnivesha, Caraka Samhita, edited by Yadavjee Trikramjee Acharya, Chaukhamba Sanskrit Sansthan Varanasi 2007, p152.

\section{Source of Support: Nil \\ Conflict of Interest: None Declared}

How to cite this URL: Abhijeet Sawant et al: Aamvisha Janya Amlapitta And Its Ayurvedic Management. International Ayurvedic Medical Journal \{online\} 2021 \{cited October 2021\} Available from: http://www.iamj.in/posts/images/upload/2500_2505.pdf 